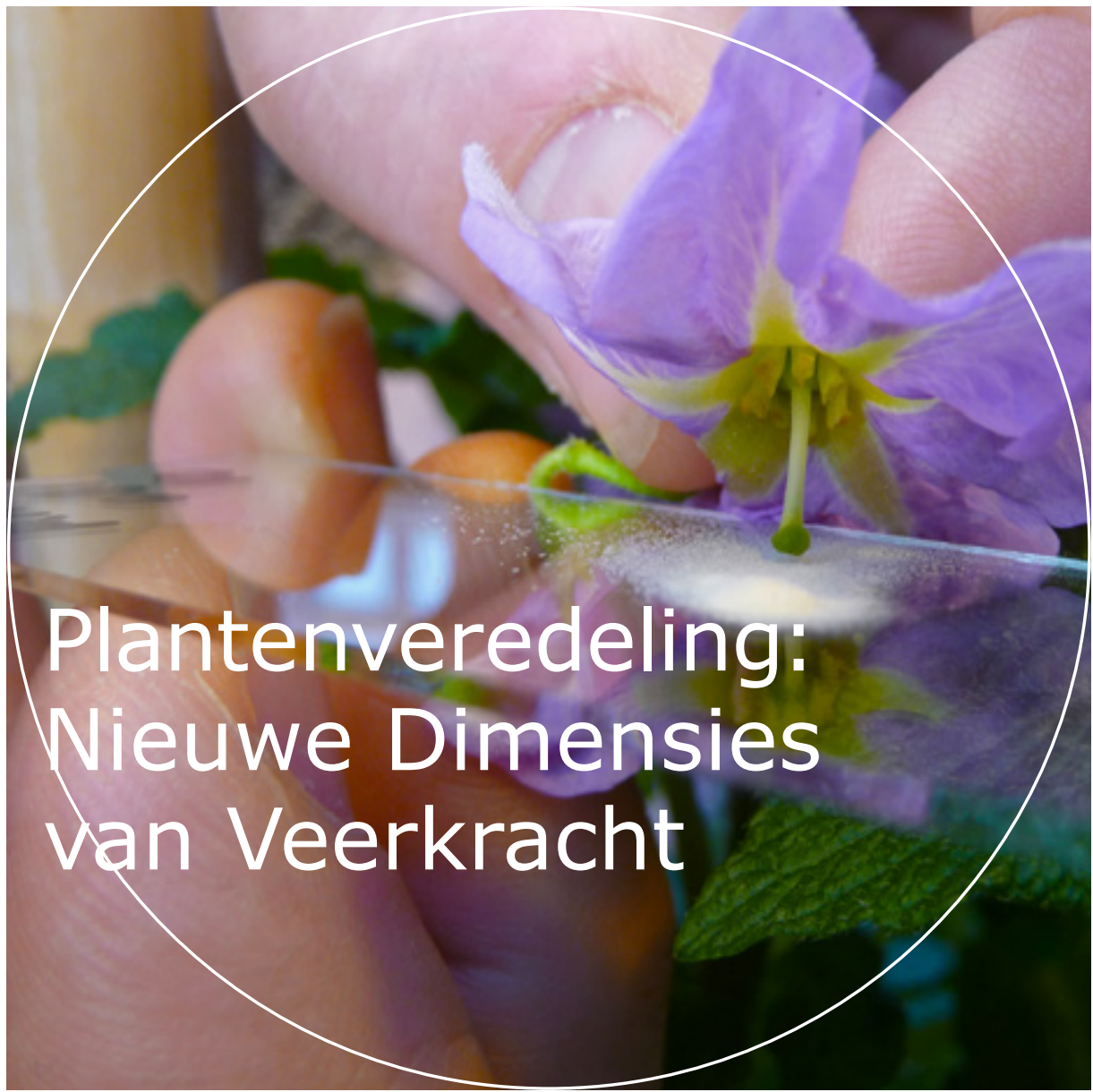

Prof. dr. ir. Edith Lammerts van Bueren

Rede bij het afscheid als buitengewoon hoogleraar

Biologische Plantenveredeling aan Wageningen University \& Research op 7 december 2017 



\section{Plantenveredeling: Nieuwe Dimensies van Veerkracht}

Prof. dr. ir. Edith Lammerts van Bueren

Rede bij het afscheid als buitengewoon hoogleraar Biologische Plantenveredeling aan Wageningen University \& Research op 7 december 2017 
DOI HTTPS://DOI.ORG/10.18174/430136 ISBN 978-94-6343-727-1 


\section{Plantenveredeling: Nieuwe Dimensies van Veerkracht}

Meneer de Rector, collega's, vrienden en familie,

Ik stel het zeer op prijs dat $\mathrm{u}$ mijn afscheidsrede bent komen bijwonen met de titel 'Plantenveredeling: nieuwe dimensies aan veerkracht'.

Met deze rede neem ik vandaag afscheid van mijn Wageningse functie, maar de kennis die ik bij Wageningen University heb opgedaan, bouwt natuurlijk voort op de kennis en ervaring die ik heb opgedaan bij het Louis Bolk Instituut (LBI) en omgekeerd. Dat is kruisbestuiving! Dus voordat ik begin, wil ik mijn erkentelijkheid tonen aan het Louis Bolk Instituut!

Allereerst wil ik graag met $\mathrm{u}$ terugkijken op bijna 40 jaar ontwikkeling van de biologische sector en specifiek van biologische plantenveredeling en zaadproductie, en het onderzoek waarbij ik betrokken ben geweest, zowel aan het Louis Bolk Instituut als aan de Wageningen University. Daarna wil ik vooruit kijken naar de uitdagingen van de toekomst op het gebied van de plantenveredeling.

\section{Mijn kennismaking met biologische landbouw}

Toen ik in 1972 naar Wageningen kwam om plantenveredeling te studeren, wist ik weinig over de landbouw, laat staan over 'alternatieve landbouw', zoals biologische landbouw toen werd genoemd. Ik heb de biologische landbouw niet ontdekt via het studieprogramma omdat biologische landbouw in die tijd als oneconomisch en onwetenschappelijk te boek stond. Ik leerde over biologische landbouw toen ik halverwege mijn studie besloot over te stappen van plantenveredeling naar tuinbouwplantenteelt om eerst een bredere basis te hebben voordat ik mij in de plantenveredeling zou gaan specialiseren. Ik kwam terecht in een nieuwe groep studenten die erg betrokken waren bij de biologische landbouw, en vanaf die tijd besloot ik me in te zetten voor deze innovatieve landbouw. 
Toen ik in 1978 afstudeerde, was er niet veel werk voor academici in de biologische landbouw. Na een aantal jaren les te hebben gegeven aan de middelbare agrarische school voor biodynamische landbouw Warmonderhof, kwam ik uiteindelijk in 1986 bij het Louis Bolk Instituut. Dit onderzoeksinstituut werd opgericht in 1976; de landbouwafdeling begon in 1978, het jaar waarin ik afstudeerde. Deze afdeling ondersteunde biologische boeren met onderzoek op de boerderij.

Later hoorde ik dat De Bolster in datzelfde jaar werd opgericht door Chris en Harry Douwes, beiden afgestudeerd in Wageningen. Ze hadden een klein bedrijf opgericht dat biologisch zaad produceerde van oude, smaakvolle en vrije rassen.

Het thema van de plantenveredeling bleef me fascineren en ik begon vanaf 1985 de eerste internationale workshops over biodynamische plantenveredeling te volgen, meestal als de enige persoon uit Nederland. Soms kwam Chris Douwes erbij.

\section{De ontwikkeling van de biologische plantenveredeling en zaad- productie}

In veel landen zijn de biologische plantenveredeling en zaadproductie bewust buiten de gevestigde orde gestart met vrije, individuele veredelaars, zoals in Duitsland en Zwitserland. Later werden zij lid van Kultursaat, een vereniging van biodynamische veredelaars (zie www.kultursaat.org).

In Nederland was dit echter anders. Hier, in de jaren '80, maakten professionele biologische telers mij heel duidelijk dat ze goede zaden nodig hadden en niet zelf het wiel opnieuw wilden uitvinden, omdat Nederland veel zaadbedrijven met veel expertise had. Zeker, er waren individuele boeren die experimenteerden met zaad- of pootgoedproductie op het eigen bedrijf zoals van granen en aardappelen, maar als iets collectief moest gebeuren dan bij voorkeur samen met de expertise van de gangbare zaadsector indien deze bereid zou zijn om biologisch zaad van specifieke rassen te produceren.

Maar er was meer nodig om die trein in Nederland in beweging te krijgen.

Terugblikkend op onze ervaring bij het Louis Bolk Instituut (Nuijten et al. 2013; 2017a), hebben we geleerd dat:

1. er een gedeeld gevoel van urgentie moet zijn voor een dergelijke innovatie en dat was aanvankelijk niet aanwezig in de Nederlandse biologische sector;

2 er individuen moeten zijn die het voortouw willen nemen;

3 instituties ook moeten bewegen om nieuwe concepten toe te passen. 


\section{Gedeeld gevoel van urgentie}

Dat gevoel van urgentie kwam pas aan het eind van de jaren ' 80 / begin jaren '9o toen er discussie over genetische manipulatie ontstond. Toen besefte de sector dat als het zijn eigen agenda niet zou formuleren, het snel geen keus zou hebben.

In 1989 begon Agrico op verzoek van biologische aardappeltelers met het produceren van biologische pootaardappelen van het ras Santé. Maar niet alle biologische aardappeltelers waren aangesloten bij Agrico. Dus drong de biologische teler Niek Vos aan bij Odin, een biologisch-dynamische handelsorganisatie, om biologische pootaardappelen van vrije rassen te gaan organiseren, maar al snel bleken de rassen van Wolf \& Wolf veelbelovend. Dat leidde in 1990 tot een joint venture tussen Odin en Wolf \& Wolf, onder de naam Bioselect, zie Foto 1. Nadat Wolf \& Wolf in 1994 fuseerde met Agrico, verkocht Odin zijn aandeel in Bioselect aan Agrico. Bioselect is vandaag de dag uitgegroeid tot een merknaam voor biologische aardappelen van Agrico en tot een van de belangrijkste leveranciers van biologische rassen. Momenteel zijn meer dan 10 aardappelveredelingsbedrijven in Nederland betrokken bij de verkoop van biologische pootaardappelen.

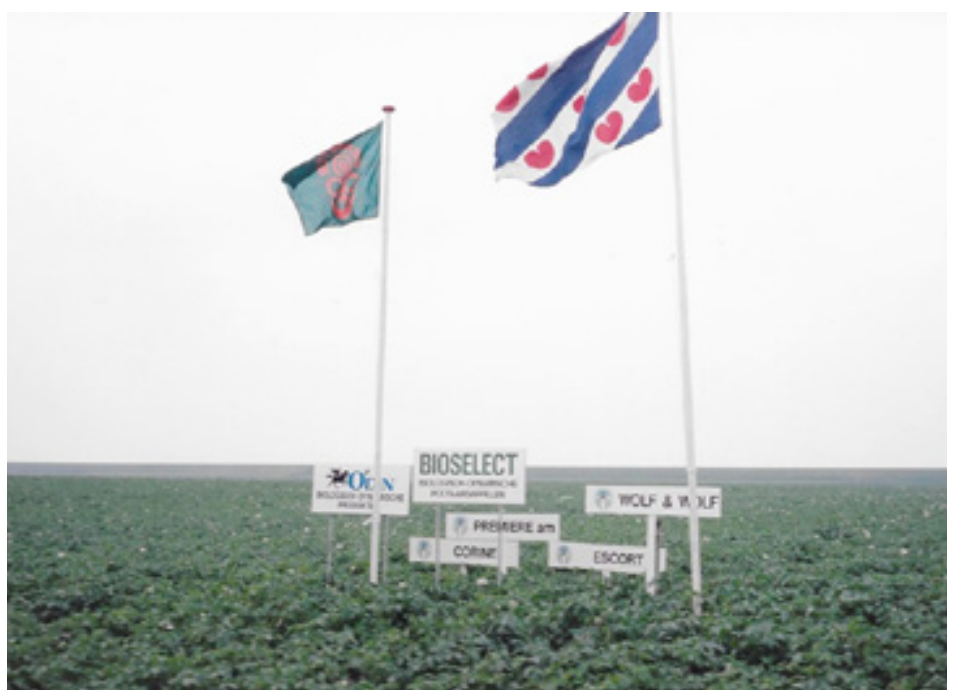

Foto 1. Oprichting van Bioselect in 1990 op het bedrijf van Asse Aukes (Fr). Foto Ad Verhage

In 1993 hebben we voor groenteteelt zes grote groentezaadbedrijven bezocht om te horen of ze bereid waren biologisch zaad te produceren. De grootste zorg in die tijd was het gebrek aan zaadbehandelingen om door zaad overgedragen ziekten te voorkomen. 


\section{Voortrekkers}

Een onverwacht resultaat van dat project was dat Jan Velema, toen werkzaam als slaveredelaar bij Rijk Zwaan, meteen begon met een experiment om slazaad te produceren in een biologische kas; dat was succesvol met een goede zaadopbrengst en een hoge kiemkracht. Om zich volledig te concentreren op biologisch zaad, richtte hij Vitalis Biologische Zaden op in 1994. Sinds 2012 is Vitalis een volle dochter van Enza Zaden.

In 1997 vroeg het Ministerie van Landbouw aan het Louis Bolk Instituut om alle veredelingstechnieken te evalueren op geschiktheid voor de biologische landbouw. Er was begrip voor het feit dat de biologische sector GGO-vrij wilde blijven, maar het Ministerie wilde ook duidelijkheid over de vele andere bestaande technieken. Samen met Marjolein Tiemens-Hulscher hebben we het eerste beoordelingskader in Europa ontwikkeld en de internationale discussies geleid over de geschiktheid van bepaalde technieken in het licht van de waarden van de biologische landbouw (Lammerts van Bueren et al. 1999; 2003). In 2002 werd ons advies omgezet in normen voor biologische veredeling door IFOAM, de internationale federatie van biologische landbouwbewegingen. En het onderzoeksinstituut FiBL in Zwitserland produceerde een kleurrijke versie ervan in vele talen (FiBL 2015). De discussie over technieken gaat nog steeds door met het verschijnen van de zogenaamde 'novel breeding techniques' (zie o.a. Nuijten et al. 2017b).

\section{Instituties moeten mee veranderen}

Ondertussen ontstond er een behoefte aan instituties om de overgang naar het gebruik van biologisch zaad te ondersteunen. De EU verplichting om biologisch geproduceerd zaad in de biologische teelt te gebruiken zou aanvankelijk in 2001 van start gaan. Maar die datum werd uitgesteld tot 2004 om de biologische sector meer tijd te gunnen. We hebben in 1998 Stichting Zaadgoed opgericht (www.zaadgoed.nl) en een eerste activiteit was om de Groene Zadengidsen te publiceren met een jaarlijks overzicht van beschikbaar biologisch zaad. Vanaf 2004 is een dergelijke inventarisatie geformaliseerd en wordt deze jaarlijks gepubliceerd op de Biodatabase van de Naktuinbouw (zie www.biodatabase.nl).

Om de belangen van biologisch zaad en veredeling in de EU te behartigen, hebben we in 2001 samen met enkele internationale partners het Europees Consortium voor Biologische Plantenveredeling (ECO-PB) opgezet (www.eco-pb.org). We stimuleerden kennisuitwisseling over hoe we de Europese regelgeving voor biologisch zaad 
konden implementeren door middel van regelmatige workshops met de belangrijkste spelers van de biologische zaadsector en overheidsinstanties uit verschillende EU-lidstaten.

\section{Nieuw moment van urgentie}

Een andere belangrijke gebeurtenis die het gevoel van urgentie voor een nieuwe stap verhoogde, was in 2006 aan het begin van het DuRPH-programma voor cisgene phytophthora-resistentie in aardappel. De biologische aardappelproductie stond onder grote druk, maar een resistent ras op basis van cisgenese zou geen oplossing zijn voor de biologische sector (Lammerts van Bueren et al. 2008).

Toen ik in 2005 net met mijn hoogleraarschap in Wageningen begon, verscheen Niek Vos met een dringend verzoek om financiering te zoeken voor grotere inspanningen voor biologische aardappelveredeling. Niek Vos was en is nog steeds een boerenkweker en stond op het punt om zijn eerste aardappelras Bionica te laten registreren. Bijna in dezelfde week kwam Ronald Hutten, een ervaren aardappelveredelaar werkzaam bij Wageningen University, met de vraag om samen met mij een biologisch aardappelveredelingsprogramma op te zetten. We hebben met z'n drieën een infrastructuur ontworpen met behulp van het bestaande hobbykwekersmodel. Maar de biologische sector was daar nog niet klaar voor. Pas in het dramatische phytophthora-jaar 2007, toen al 20\% van de biologische telers was gestopt met het telen van aardappel, vond de sector een gemeenschappelijke basis.

De sector was vastbesloten om dit project gefinancierd te krijgen en politieke druk was nodig. We nodigden het Tweede Kamerlid voor de PvdA en tevens biologisch boer Harm Evert Waalkens uit om te komen kijken naar de aardappelveredeling op de boerderij van Niek Vos. En dat werkte! Waalkens diende eind 2008 een amendement op de landbouwbegroting in de Tweede Kamer in en dat werd geaccepteerd! Het politieke argument was dat, hoewel de regering de biotechnologie wilde ondersteunen, zij het ook belangrijk vond dat de consument vrije keuze zou blijven houden. Bioimpuls kon in 2009 starten en zal lopen tot eind 2019 (zie www.louisbolk.org/bioimpuls/).

Voor het Ministerie van Landbouw was deze ontwikkeling een argument om een tienjarig Groene Veredelingsprogramma te starten om meer uitdagingen aan te pakken in veredelingsonderzoek die relevant zijn voor zowel de conventionele als de biologische sector (zie www.groeneveredeling.nl). Bioimpuls is nu een van de projecten. Internationaal wordt dit type samenwerking tussen conventionele en biologische sector als uniek beschouwd. 
Het volgende markeringspunt was zomer 2016: wederom een rampzalig phytophthora-jaar en veel commotie over kopergebruik in de biologische teelt. Biologische telers bereikten overeenstemming om de transitie naar robuuste rassen te maken. Inmiddels waren er zo'n to resistente rassen beschikbaar en meer in de pijplijn. Maar de hoeveelheid pootaardappelen was slechts voldoende voor $30 \%$ van de biologische aardappelsector.

Telersverenigingen, Bionext en Louis Bolk Instituut ontwikkelden een transitieplan, inclusief de realisatie van een convenant met de supermarktketens om robuuste rassen voor het biologische segment te prioriteren. Binnen een jaar, in augustus 2017, werd het convenant ondertekend en intussen hebben alle supermarktketens zich aangemeld. Met deze cruciale verbintenis kan de sector opschalen naar voldoende hoeveelheden biologisch pootgoed om de vraag van zowel telers als retailers in 2020 volledig te dekken. Interessant is dat ook conventionele boeren deze rassen beginnen te verbouwen.

\section{Nieuwe instituties rond rasconcepten}

Niet alleen het collectieve gevoel van urgentie is vereist. Ook instituties moeten veranderen, bijvoorbeeld door andere rasconcepten te accepteren. Voorbeelden zijn het aanpassen van de protocollen voor het testen van rassen en voor hun registratie. Veel eigenschappen die belangrijk zijn voor de biologische landbouw worden niet waargenomen in de standaardprotocollen voor granen en dit voorkomt dat rassen op de markt verschijnen met eigenschappen die cruciaal zijn voor biologische boeren, waaronder voldoende weerstand tegen ziekten, vroege groeikracht en onkruidonderdrukkend vermogen; zie Foto $2 \mathrm{a}$ en $2 \mathrm{~b}$.

Het onderzoek over dit onderwerp door Aart Osman van het Louis Bolk Instituut leidde in 2004 tot een speciaal protocol voor het Cultuur- en Gebruikswaarde Onderzoek (CGO) voor biologische zomertarwe (Osman et al. 2015), en veel Europese landen volgden, voornamelijk voor granen.

Momenteel wordt nog een ander rasconcept toegepast in de biologische plantenveredeling op basis van genetische diversiteit, zoals populaties (composite cross populations) in granen, zie Foto 3. Het veredelen van dergelijke populaties voor low-input landbouw is een manier om de buffercapaciteit te verbeteren tegen variabele en onvoorspelbare weersomstandigheden en daarmee samenhangende ziektedruk. Maar dat druist in tegen de zuivere lijn selectie waarop de regelgeving is gebaseerd. 

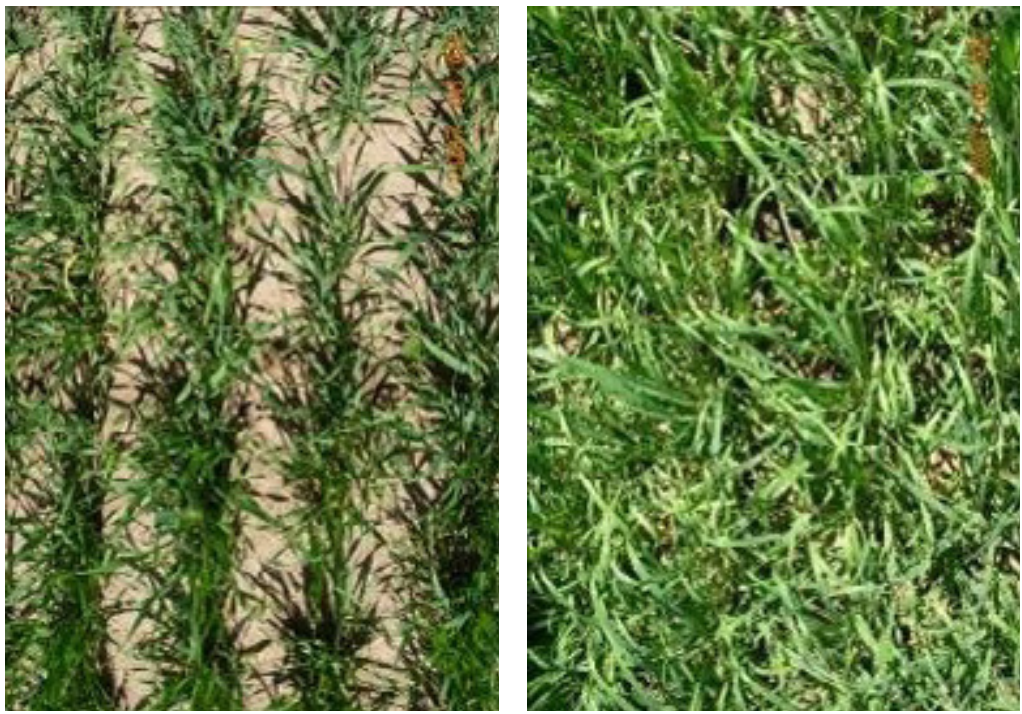

Foto's $2 a$ en $2 b$. Verschillen in slechte ( $a$ ) en goede ( $b$ ) onkruidonderdrukking bij gerst.

Foto Aina Kokare/Letland

Op verzoek van de biologische sector heeft Brussel een experiment toegestaan in verschillende EU-landen, waaronder Nederland, om te onderzoeken hoe dergelijk 'heterogeen materiaal', zoals het wordt genoemd, zodanig kan worden beschreven dat het onderscheidbaar wordt en legaal op de markt kan worden gebracht. In de tussentijd willen veredelaars die rassen onder biologische omstandigheden hebben veredeld volgens specifieke normen, hun rassen in de markt onderscheiden. Daartoe wordt in februari 2018 het Bioverita-label gelanceerd op de internationale BioFach-beurs in Neurenberg (D).

\section{LIVESEED: Europees onderzoek voor biologische zaadproductie en plantenveredeling}

De productie van biologisch zaad neemt wereldwijd toe en heeft de weg vrijgemaakt voor het ontwikkelen van biologische veredeling. Het thema van biologische plantenveredeling is een internationaal erkend onderwerp van wetenschappelijk onderzoek geworden aan verschillende universiteiten in Europa en daarbuiten. Maar we zijn nog ver verwijderd van 100\% dekking en gebruik van biologisch zaad in de biologische landbouw. Deze zomer startten we het EU-project LIVESEED (2017-2021), met een groot consortium van 35 partners en 18 landen met een totaal budget van 8 miljoen euro, in de hoop de productie van biologisch zaad en veredeling in de komende jaren te stimuleren (zie www.liveseed.eu). 


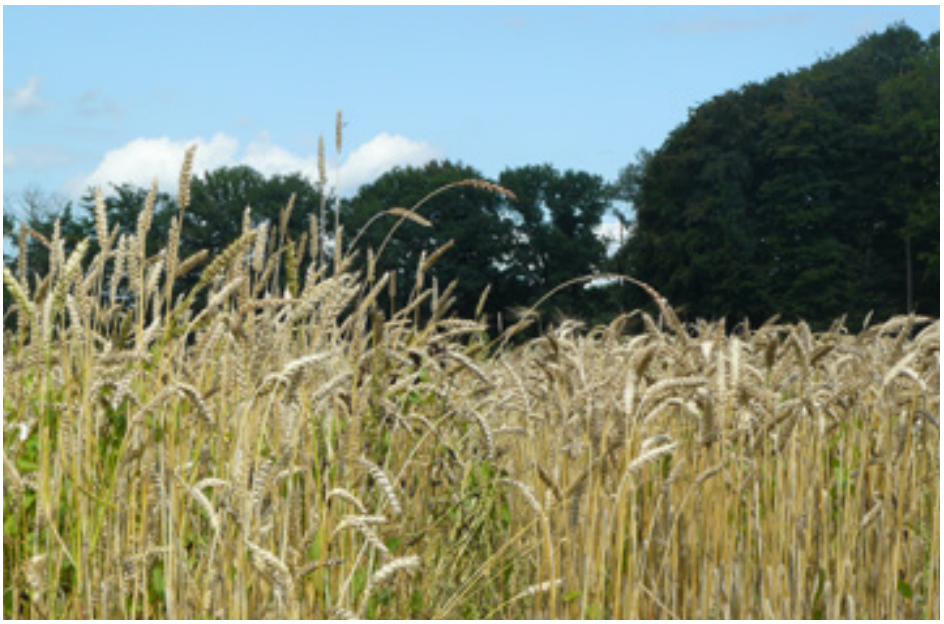

Foto 3. Links een populatie ras (composite cross population) versus zuivere lijn in wintertarwe (rechts). Foto Edwin Nuijten/LBI

\section{De Leerstoel Biologische Plantenveredeling}

De oprichting van de buitengewone leerstoel Biologische Plantenveredeling heeft een extra impuls gegeven aan de zichtbaarheid van de behoefte aan nieuwe concepten en strategieën voor aangepaste rassen voor de biologische landbouw. De uitdaging was om te laten zien dat biologische plantenveredeling

- een wetenschappelijk en innovatief onderzoeksgebied is,

- voldoende wetenschappelijke output biedt,

- en voldoende MSc-studenten aantrekt, zie Foto 4a en b.
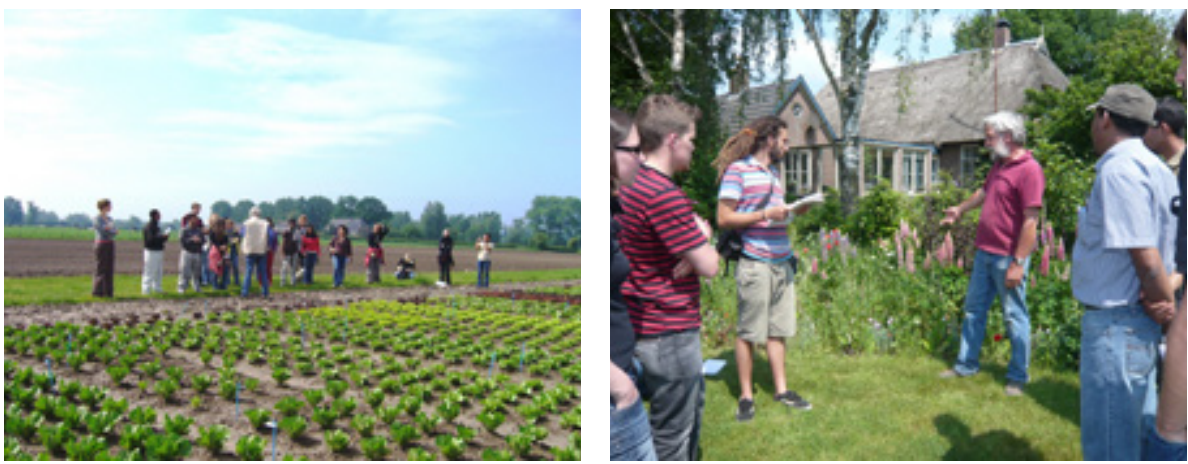

Foto 4a en b. Excursie naar Vitalis (foto links) en De Bolster (foto rechts) met MSc studenten van de cursus Organic Plant Breeding. Foto Edith Lammerts van Bueren/WU 
Mijn persoonlijke ambitie was om de discipline van biologische plantenveredeling binnen Wageningen University te verankeren, maar ook om het daarbuiten een gezicht te geven. Met plezier zette ik me in om de kloof te overbruggen tussen biologische landbouwpraktijk in academisch onderzoek en netwerk. Ik heb mede gezamenlijke optredens tijdens de publieksdagen van de DuRPH- en Bioimpulsprogramma's ontwikkeld (zie Foto 5), waarbij ik mijn GGO-gedreven collega's als 'broeders en zusters in de wetenschap' respecteerde om weg te komen van de polarisatie en het publiek te laten zien dat er meerdere wegen naar Rome leiden, en dat innovatie kan worden bereikt door samenwerking tussen biologische en gangbare veredeling. Maar ik bleef altijd binnen de gegeven kaders van de biologische landbouw.

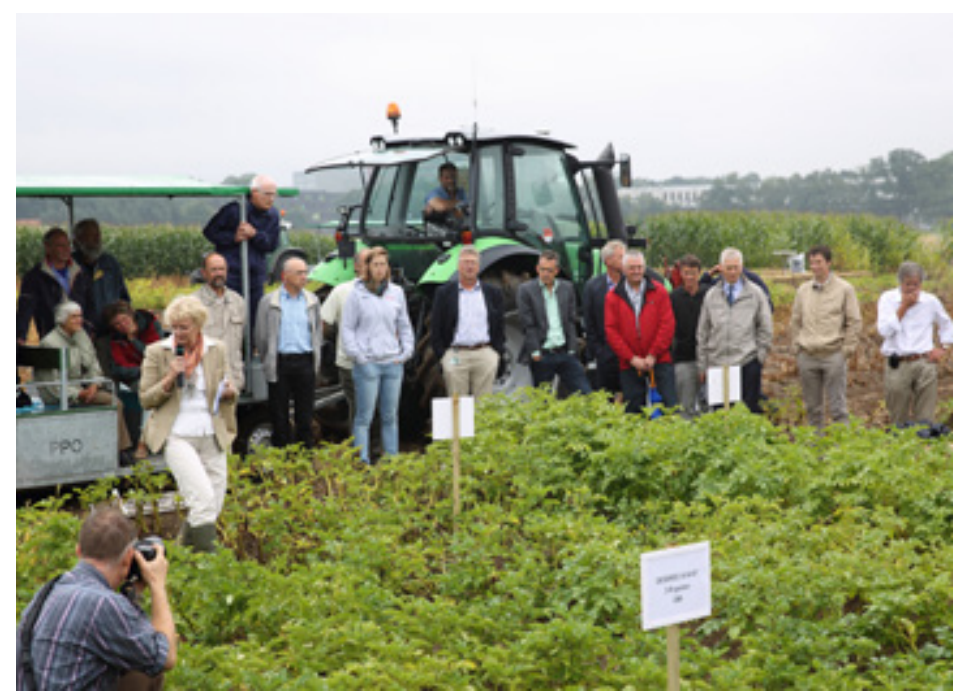

Foto 5. Edith was veelvuldig spreker tijdens publieke debatten zoals over cisgenese versus biologische veredeling van aardappel, Wageningen 2013. Foto Biojournaal

De uitdaging blijft om aan te tonen dat hoewel klassieke veredelingstechnieken worden gebruikt, ze nieuwe kennis en nieuwe inzichten genereren in een andere context en daarom wetenschappelijk innovatief kunnen zijn.

In 2009 stimuleerde ik de discussie over de rol van moleculaire markers in biologische veredelingsprogramma's door biologische en gangbare praktische veredelaars bij elkaar te brengen. De conclusie was dat moleculaire markers bruikbaar kunnen zijn in biologische veredelingsprogramma's, soms zelfs noodzakelijk, bijvoorbeeld bij het stapelen van diverse phytophthora-resistentiegenen (Lammerts van Bueren et al. 2010). 


\section{Ondergrondse raseigenschappen}

Veel van mijn onderzoek in Wageningen was gericht op ondergrondse raskenmerken. We veronderstelden dat een betere wortelarchitectuur en grotere wortelbiomassa een mogelijke sleutel tot robuustheid in sla was. De resultaten toonden aan dat het niet zozeer gaat om de totale wortelmassa, maar om het vermogen van een ras om met extra, fijne haarwortelvorming snel te reageren op een veranderende situatie. Het goede nieuws is dat er nog steeds genetische variatie bestaat voor dergelijke flexibiliteit bij moderne slarassen en dat deze verder moet worden benut in de veredeling!

Het analyseren van eigenschappen onder de grond is zeer arbeidsintensief, dus heb ik van de gelegenheid gebruik gemaakt om te onderzoeken of moleculaire markers een hulpmiddel kunnen zijn bij de selectie van dergelijke complexe eigenschappen. We zagen in experimenten met 150 rassen dat er significante variatie was tussen rassen in hun reactie op de seizoen-specifieke weerpatronen en daarom werden verschillende merker-raseigenschap combinaties in verschillende seizoenen geïdentificeerd voor de totale hoeveelheid overgebleven nitraat over het bodemprofiel van $40 \mathrm{~cm}$ als een maat voor nitraatopname-efficiëntie (Kerbiriou et al. 2016). Hoewel genetisch onderzoek een beter begrip van fysiologische processen op moleculair niveau mogelijk maakt, blijft het veredelen voor dergelijke ondergrondse eigenschappen zeer complex.

Een thema dat aan ondergrondse raseigenschappen is gerelateerd, is het ontwikkelen van een veredelingsstrategie voor de efficiëntie van stikstofopname en -gebruik in spinazie, sla, aardappelen en kool. Veredelaars weten vaak dat rassen verschillen in hun behoefte aan stikstof, maar weten niet hoe ze moeten worden geselecteerd. De resultaten met deze verschillende gewassen zijn samengevat in een overzichtsartikel dat illustreert dat soorten aanzienlijk verschillen in benadering, maar dat er genoeg variatie is tussen moderne rassen om te selecteren voor stikstof-efficiëntie (Lammerts van Bueren en Struik 2017).

\section{Selectieomstandigheden}

Een andere belangrijke vraag voor de veredelingssector is of men per se onder biologische omstandigheden moet selecteren om rassen te ontwikkelen die zijn aangepast aan biologische landbouwsystemen. Voor veel conventionele veredelingsbedrijven die de biologische markt willen bedienen, is het onmogelijk om twee 
afzonderlijke programma's uit te voeren, dus zoeken ze naar strategieën om beide programma's te integreren.

Een veredelaar uit Letland, een van mijn externe promovendi, heeft dit uitgebreid onderzocht in een uniek selectieprogramma met twee verschillende kruisingspopulaties van gerst (Kokare et al. 2017). Ze toonde aan dat het mogelijk is om te selecteren onder conventionele teeltomstandigheden, als niet alleen wordt geselecteerd op opbrengst, maar ook op eigenschappen die relevant zijn voor de biologische landbouw, zoals het vermogen om onkruid te onderdrukken.

We moeten er echter rekening mee houden dat een conventioneel selectieveld normaliter wordt beheerd met herbiciden, dus men kan alleen indirect selecteren op onkruidonderdrukkend vermogen door middel van morfologische eigenschappen zoals gewasarchitectuur. Dit zijn eigenschappen met een hoge erfelijkheid waarop relatief onafhankelijk van de teeltomgeving kan worden geselecteerd. In conventionele selectievelden worden ook minerale meststoffen gebruikt die gemakkelijk door de plant worden opgenomen. Verschillen tussen rassen/lijnen in het omgaan met verminderde beschikbaarheid van voedingsstoffen uit organische mest in een koude lente komen niet tot uiting. Mineralisatie resulterend in beschikbaarheid van mineralen voor de plant, hangt af van de activiteit van het bodemleven en bodemtemperatuur. Selectie in de laatste jaren van een veredelingsprogramma zal dus moeten plaatsvinden onder biologische veldomstandigheden.

\section{Kenmerken van een biologische plantenveredeling}

Met dit voorbeeld heb ik laten zien dat biologische teelt niet alleen een kwestie is van het weglaten van chemie, maar dat het ook andere agronomische maatregelen en raseigenschappen in een veredelingsprogramma vereist om minder afhankelijk te worden van externe chemische inputs (Lammerts van Bueren et al. 2002). In Tabel 1 is een overzicht gegeven van eigenschappen die van belang zijn voor landbouw met weinig externe inputs. 
Tabel 1. Consequenties van een biologische teeltregime voor het prioriteren van veredelingsdoelen

\begin{tabular}{lll}
\hline Teeltmaatregel & Veredelingsdoelen \\
\hline $\begin{array}{l}\text { Geen minerale bemesting, maar lagere N niveaus } \\
\text { van langzaam vrijkomende organische meststoffen }\end{array}$ & $\bullet$ & $\begin{array}{l}\text { Stikstofefficiëntie } \\
\text { Vroege groeikracht } \\
\text { Dieper wortelend }\end{array}$ \\
\hline $\begin{array}{l}\text { Geen herbiciden en behoefte om arbeid in onkruid- } \\
\text { beheersing te reduceren }\end{array}$ & $\bullet$ & $\begin{array}{l}\text { Onkruidonderdrukkend- en goed } \\
\text { concurrentievermogen }\end{array}$ \\
\hline Geen chemische ziekten- en plagenbestrijding & $\bullet$ & Vroege groeikracht \\
\hline $\begin{array}{l}\text { Geen genetische modificatie-technieken } \\
\text { Minder mogelijkheden om tijdens de teelt de groei van }\end{array}$ & $\bullet$ & $\begin{array}{l}\text { Hoge mate van resistentie of veldtolerantie } \\
\text { Geinduceerde resistentie } \\
\text { Genetische variatie }\end{array}$ \\
\hline
\end{tabular}

Kortom, biologisch veredelen is niet zozeer veredelen voor een andere markt, als wel veredelen voor een ander managementsysteem dat gericht is op het verbeteren van de ecologische veerkracht van de landbouwsystemen terwijl het onafhankelijk is van externe chemische inputs.

Maar er is meer om naar te streven en ik zal nu de toekomstige uitdagingen bespreken.

\section{Naar een ecologisch en sociaal veerkrachtige landbouw}

Biologische landbouw zal ook andere gebieden met betrekking tot duurzaamheid moeten ontwikkelen. Een IFOAM-denktank waaraan ik deelnam, schetste in 2015 dat de biologische sector niet alleen in omvang zou moeten groeien (mogelijk tot $20 \%$ om meer kritische massa te bereiken), maar ook bredere maatschappelijke doelstellingen moet gaan omarmen zoals getoond in de volgende duurzaamheidsbloem: ecologie, samenleving, cultuur, verantwoording en economie (Arbenz et al. 2016).

Dit is in lijn met de Sustainable Development Goals (SDGs) die de VN in 2015 hebben gepresenteerd (VN 2015). 


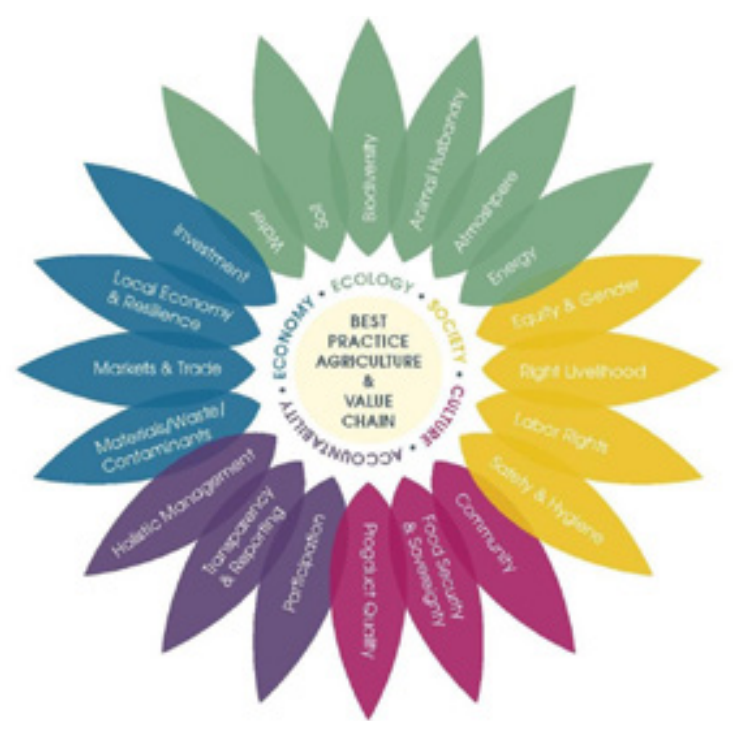

Figuur 1. IFOAM's duurzaamheidsbloem met de vijf dimensies: ecologie, maatschappij, cultuur, verantwoording en economie (Arbenz et al. 2016)

\section{Naar een plantenveredeling die bijdraagt aan ecologische en sociale veerkracht}

Deze SDGs moeten ook worden vertaald in aspecten van veredeling. Daarom stellen we zes veredelingsdoelen voor, niet alleen voor de biologische plantenveredeling, maar ook voor de plantenveredeling in het algemeen:

- sociale rechtvaardigheid;

- voedselzekerheid, -kwaliteit en -veiligheid;

- voedsel- en zaadsoevereiniteit;

- agrobiodiversiteit;

- ecosysteemdiensten;

- klimaatrobuustheid.

We moeten de duurzaamheid van de productiesystemen, voedselzekerheid en voedselveiligheid herstellen voor een snelgroeiende en steeds veeleisender wordende wereldbevolking. Maar, er is ook de zorg dat de diversiteit van gewassen achteruitgaat. Nationale diëten worden steeds diverser, maar wereldwijd worden diëten steeds uniformer (Khoury et al., 2014).

Veel bruikbare gewassen met een relatief klein areaal zijn 'wees' geworden waarvoor geen veredeling meer wordt uitgevoerd, waardoor de afhankelijkheid van het 
wereldvoedselsysteem van een beperkt aantal gewassen toeneemt. Van de 30.000 eetbare soorten telen we er slechts 150, en 95\% van onze humane voedselcalorieën zijn afkomstig van slechts 30 soorten (Dwivedi et al. 2017).

Biodiversiteit en ecosysteemdiensten zijn sleutelfactoren die het milieu binnen agro-ecosystemen reguleren en ondersteunen en de toekomstige voedselproductie waarborgen.

Belangrijke ecosysteemdiensten zijn:

- natuurlijke ziekten- en plaagbestrijding;

- bestuiving;

- nutriënten kringloop;

- bodembescherming (structuur en vruchtbaarheid);

- watervoorziening (kwaliteit en kwantiteit);

- koolstofvastlegging.

Franse onderzoekers toonden aan dat met moderne plantenveredeling de bloemmorfologie van peulvruchten, zoals van veldbonen (zie Foto 6), minder toegankelijk is geworden voor bestuivers (Suso et al. 2016).

Mijn collega's bij het LBI hebben gemerkt dat sommige klaverrassen om dezelfde reden worden genegeerd door bestuivers. Veredelaars moeten rekening houden met dergelijke bloemkenmerken, omdat onze voedingsgewassen ook voedsel voor bestuivers moeten leveren om zo bij te kunnen dragen aan ecosysteemdiensten.

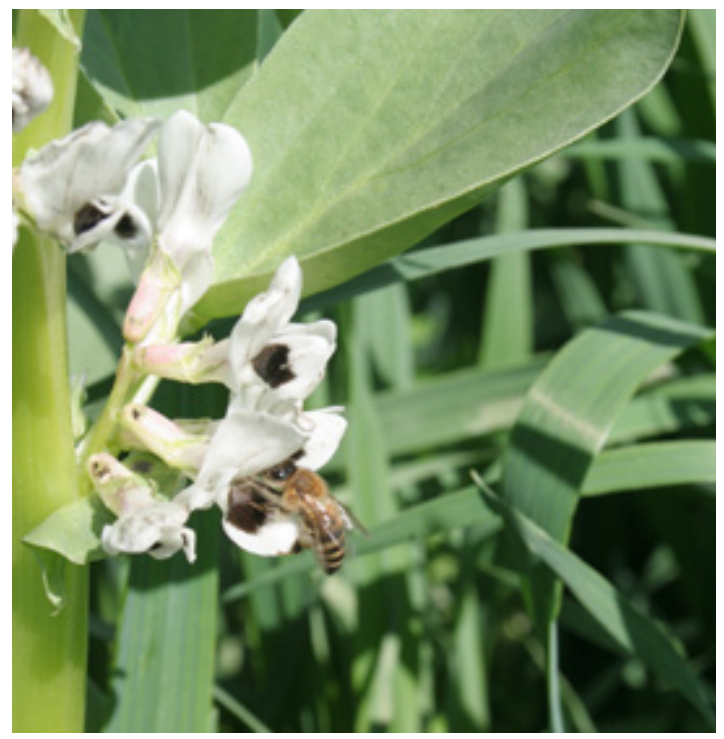

Foto 6. Bloemvorm van veldboon (Vicia faba L.) moet toegankelijk blijven voor bestuivers.

Foto Udo Prins/LBI 
Mijn collega's hebben ook grasrassen geanalyseerd op genetische variatie in wortelmassa in relatie tot ecosysteemdiensten (Deru et al. 2014). Sommige rassen produceren niet alleen een goede grasopbrengst, maar produceren ook een grote wortelbiomassa, zie Foto 7. Dergelijke rassen zijn hard nodig om het organische stofgehalte in de bodem te verbeteren, hetgeen het watervasthoudend en doorlatend vermogen beïnvloedt; ze dragen ook bij tot koolstofvastlegging in de bodem. Maar dat heeft nog geen aandacht gekregen van veredelaars.

Tegelijkertijd moet de landbouwproductie ook klimaatrobuust worden gemaakt: veredelaars moeten flexibele rassen ontwikkelen die bestand zijn tegen steeds meer onvoorspelbare en extreme weerspatronen. Het realiseren van deze doelen vereist 'duurzame intensivering'. Duurzame intensivering is alleen mogelijk met substantiele en langdurige inspanningen van alle spelers in het voedselsysteem, inclusief veredelaars.

Deze uitdagingen kunnen niet alleen door technische oplossingen worden opgepakt, maar vereisen oplossingen die rekening houden met sociaal-economische, ethische en juridische aspecten. Daarom is een integrale aanpak nodig om de ecologische veerkracht in combinatie met de sociale veerkracht te versterken.

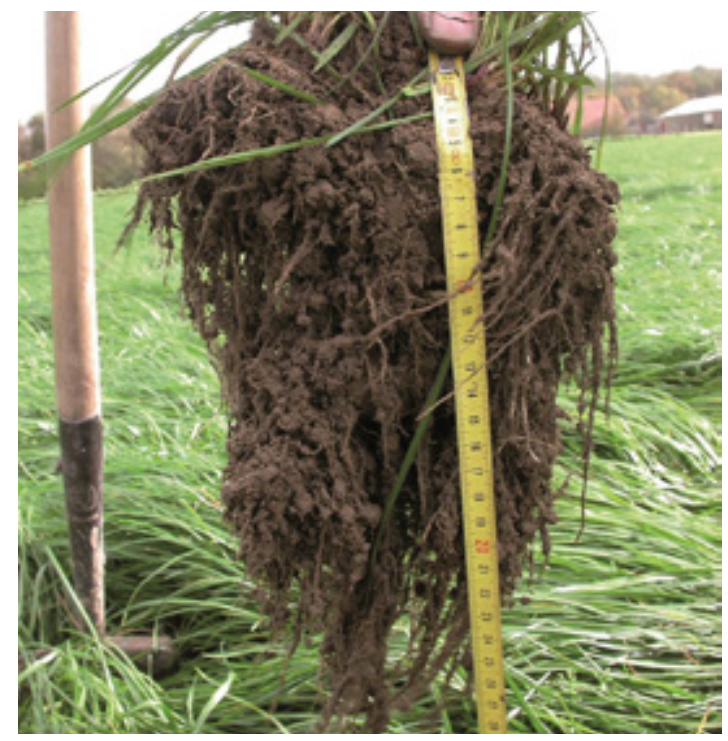

Foto 7. Sommige rassen produceren niet alleen een goede grasopbrengst, maar produceren ook een grote wortelbiomassa. Foto Coen ter Berg/LBI 


\section{Moderne veredeling in het maatschappelijke debat}

De huidige ontwikkelingen in de moderne plantenveredeling hebben echter geleid tot verzet van maatschappelijke organisaties. Het debat heeft betrekking op verschillende kwesties: sociale rechtvaardigheid en voedselsoevereiniteit, eigendom van genetische hulpbronnen, boerenrechten op eigen zaadreproductie, octrooieren van plantaardig materiaal, verbetering van kleine gewassen om de diversiteit van gewassen te behouden, acceptatie van nieuwe veredelingstechnieken, de monopolies en fusies van grote multinationals, en de koppelverkoop van genetische modificeerde herbicide-resistente rassen en herbiciden.

Zaden zijn essentieel en daarom moet plantenveredeling centraal staan in het maatschappelijk debat over de toekomst van de landbouw.

\section{Vier denkrichtingen in de veredeling}

Om de verandering in de tijd van plantenveredeling in verschillende oriëntaties te analyseren, hebben we een analysekader ontwikkeld (Lammerts van Bueren et al. 2017). Dit raamwerk definieert vier veredelingsoriëntaties die voortkomen uit verschillende combinaties van subjectivisme en objectivisme enerzijds en van holisme en reductionisme anderzijds en wordt geillustreerd in Figuur 2. Deze vier oriëntaties hebben verschillende denkstijlen. We noemen ze: 1) community-based veredelen, 2) ecosystem-based veredelen, 3) trait-based veredelen, en 4) corporate-based veredelen.

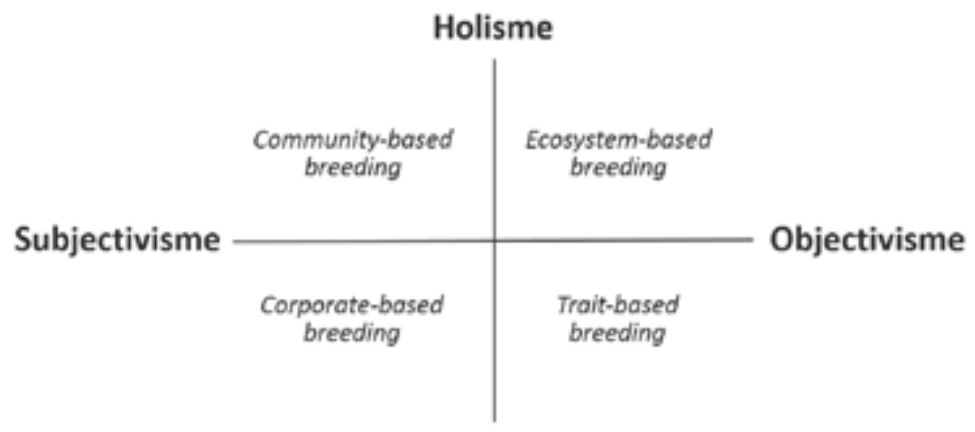

\section{Reductionisme}

Figuur 2. Vier veredelingsoriëntaties als functie van verschillende posities tussen subjectivisme en objectivisme, en tussen holisme en reductionisme. (naar Lammerts van Bueren et al. 2017) 
De oriëntatie in het kwadrant linksboven in de figuur (community-based) kan worden beschouwd als een innovatieve herinterpretatie van de voormalige informele veredeling- en zaadsystemen zoals die momenteel bestaan in ontwikkelingslanden onder kleine boerengemeenschappen. Deze benaderingen zijn verfijnd in recente veredelings- en zaadallianties als onderdeel van nieuwe voedselsystemen in verschillende delen van de wereld. Er zijn steeds meer voorbeelden van dergelijke multiactorbenaderingen, georganiseerd of ondersteund door ngo's in westerse landen die de veredeling verbeteren voor regionale rassen die zijn aangepast aan lokale, circulaire economieën, zoals de Organic Seed Alliance in de Verenigde Staten van Amerika en Réseau Semences Paysannes in Frankrijk.

De oriëntatie in de rechterbovenhoek van de figuur (ecosystem-based) wordt vertegenwoordigd door internationale initiatieven zoals het CG-systeem in de jaren 1960 tot 1980, resulterend in technologiepakketten (nieuwe zaden met kunstmest en irrigatie), en momenteel opnieuw uitgevonden met een sterkere focus op pakketten van ecosysteemdiensten. Maar tot nu toe is dit meer in het onderzoek opgepakt dan in de praktische veredeling. Deze twee bovenste oriëntaties zijn nog steeds in statu nascendi en nog niet volledig geïnstitutionaliseerd.

De twee reductionistische paradigmatische posities (corporate-based en trait-based veredelingsoriëntaties) in het onderste deel van de figuur vormen de momenteel dominante denkstijlen in de meeste geïndustrialiseerde landen en worden vertegenwoordigd door commerciële veredelingsmultinationals. De oriëntatie in het kwadrant linksonder streeft naar specifieke wensen en behoeften van de markt, terwijl de oriëntatie in het kwadrant rechtsonder gericht is op raseigenschappen die de samenleving dienen en op het analyseren van de genetica achter gewenste eigenschappen.

Terwijl de twee veredelingsoriëntaties aan de linkerkant van de figuur sterk worden bepaald door subjectieve doelstellingen van individuele commerciële bedrijven (corporate-based) of individuele gemeenschappen (community-based), worden de twee oriëntaties aan de rechterkant van de figuur gedreven door objectieve doelen die betere prestaties van gewassen ondersteunen door eigenschappen te ontleden in onderliggende componenten op zoek naar betere voorspelbaarheid en controleerbaarheid (trait-based) of zich richten op diversificatie door rassen aan te passen aan de juiste omgeving (ecosystem-based). 


\section{Naar een vijfde veredelingsoriëntatie: 'systems-based breeding'}

Elk van deze vier veredelingsoriëntaties heeft zijn sterke en zwakke punten. Bovendien hebben de vier oriëntaties elk verschillende waarden die leiden tot verschillende keuzes en beslissingen over afwegingen en risico's. Geen van de vier oriëntaties is inherent goed of slecht. Geen van hen alleen kan volledig en van harte bijdragen aan de realisatie van een productieve, werkelijk duurzame landbouw. Elk van de oriëntaties begrijpt, interpreteert en operationaliseert de zes beleidsdoelen: agrobiodiversiteit, ecosysteemdiensten, klimaatrobuustheid, voedselzekerheid en veiligheid, voedselsoevereiniteit en sociale rechtvaardigheid op verschillende manieren.

Om een veredelingssysteem te creëren dat alle zes doelen haalt en veredelingsproducten levert die kunnen voldoen aan de uiteenlopende eisen van alle actoren in de voedselwaardeketen en de samenleving als geheel, is het noodzakelijk om meer te doen dan het combineren van de sterke punten en waardevolle troeven van de verschillende paradigmatische posities. Dit vereist een nieuw type denken in de vorm van een overkoepelende, integratieve, vijfde denkstijl, die we 'systems-based breeding' hebben genoemd, zie Figuur 3.

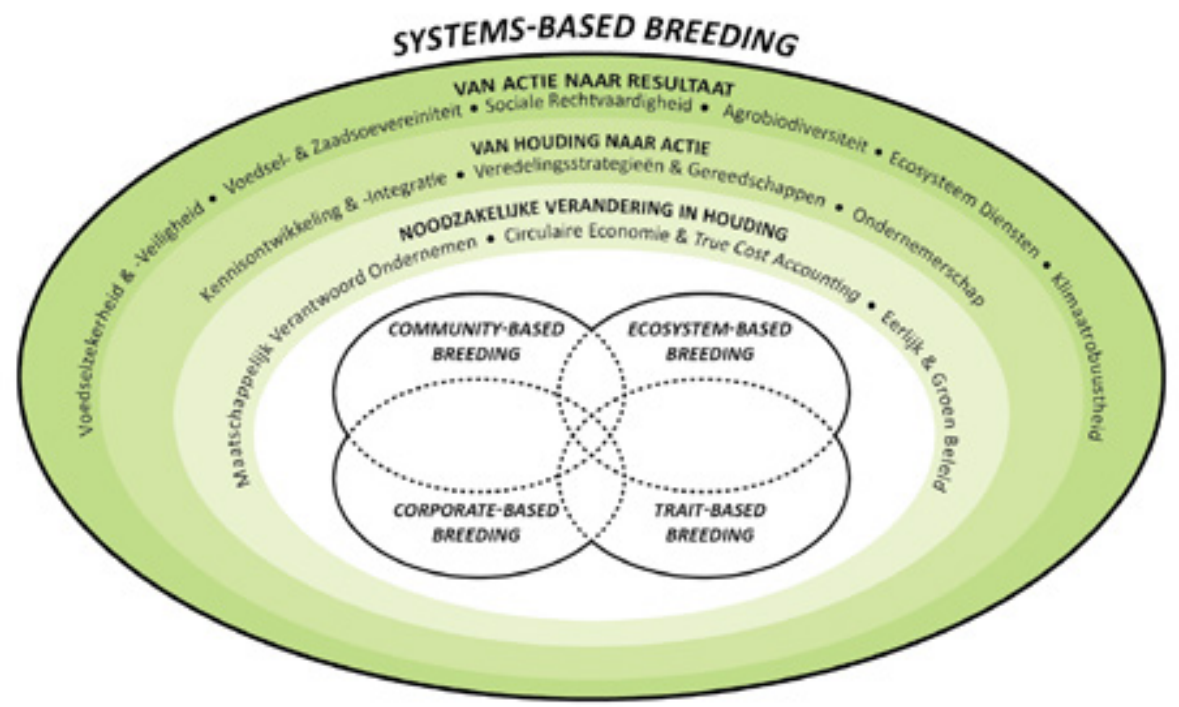

Figuur 3 Systems-based breeding als een viffde overkoepelende veredelingsoriëntatie die de positieve elementen van de vier eerdergenoemde veredelingsoriëntaties integreert. (Naar Lammerts van Bueren et al. 2017) 
Deze op systeem-gebaseerde veredelingsoriëntatie moet de synergie tussen de sterke punten van de vier benaderingen maximaliseren en nieuwe manieren ontwikkelen om plantenveredeling zodanig te organiseren dat de toekomstige uitdagingen gerealiseerd kunnen worden.

'Systeem' wordt hier gedefinieerd als de ruimte die verschillende met elkaar verbonden en onderling afhankelijke componenten van het gehele systeem omvat, waaronder:

- het maatschappelijk veld (met zijn diversiteit aan culturele normen en waarden);

- het beleid;

- de natuur;

- de landbouw (inclusief de diversiteit van agro-ecosystemen en landbouwsystemen);

- en de diverse waardeketens en markten.

\section{Vereiste mentaliteitsverandering}

Systeem-gebaseerde veredeling moet systeemgericht zijn, zowel door zijn focus op de holistische beleidsdoelen als door zijn methodologie die holistische en reductionistische benaderingen integreert.

Om alle spelers in staat te stellen vanuit systeemdenken te handelen, is er een mentaliteitswijziging nodig van particuliere bedrijven, producenten, burgers en beleidsmakers. Dit vereist meer maatschappelijk verantwoord ondernemen, het toepassen van circulaire economie en waarachtige kostenberekening (true-cost accounting), en ondersteuning met eerlijk en groen beleid.

Er zijn al uitgangspunten om op voort te borduren. Er zijn voorbeelden van het opnemen van aspecten van sociale rechtvaardigheid door een deel van de winst te delen door medewerkers binnen het veredelingsbedrijf uit te nodigen aandeelhouder te worden (zoals bij Rijk Zwaan). Maar er is ook een voorbeeld dat verder gaat, b.v. in de VS bij het veredelingsbedrijf Johnny's, dat onlangs voor de volle $100 \%$ in handen van de werknemers is gekomen.

Circulaire economie en True Cost Accounting zijn relatief nieuwe benaderingen. Onlangs (2017) behaalde Volkert Engelsman, de CEO van de grootste Nederlandse biologische handelsorganisatie van groenten en fruit Eosta, de eerste plaats in Trouw's Duurzame Top 100. Hij ontwikkelde een methodologie voor True Cost Accounting die de werkelijke ecologische en maatschappelijke kosten van zijn fruitproducten laat zien (Eosta et al. 2017).

Het zal een uitdaging zijn om veredelingsactiviteiten te organiseren volgens de vereiste mentaliteitsverandering. We moeten leren rassen te ontwikkelen die de ecologische en maatschappelijke kosten van de veredeling en haar producten kunnen verminderen. 


\section{Van mentaliteitsverandering naar actie}

Er is ook behoefte aan factoren die ons van houding naar actie brengen, zoals kennisontwikkeling en -integratie, veredelingsstrategieën en -hulpmiddelen en ondernemerschap. Het ontwikkelen van een op systeem-gebaseerde veredelingsorientatie kan alleen werken wanneer alle actoren in het voedselsysteem het voedselsysteem als geheel beschouwen, hun eigen rol in het systeem correct interpreteren en de rol van de andere spelers in het systeem begrijpen, inclusief de relevantie van interacties en synergiën. In de literatuur wordt dit 'eco-geschoold' genoemd (Capra 1997). Maar er zijn ook nieuwe ondernemingen vereist, inclusief alle vaardigheden om gezonde ondernemingsmodellen in de veredeling en zaadproductie te ontwikkelen die geschikt zijn voor diverse kleine en grote waardeketens en markten.

\section{Van actie naar resultaat}

En dan tenslotte van actie naar resultaat. Het doel van systeem-gebaseerd veredelen is de ecologische en maatschappelijke veerkracht te verbeteren door de eerder genoemde doelen op te nemen: voedselzekerheid, -kwaliteit en -veiligheid, voedselen zaadsoevereiniteit, en sociale rechtvaardigheid zonder de duurzaamheid van de ecologische context op lange termijn in gevaar te brengen door agrobiodiversiteit, ecosysteemdiensten en klimaatrobuustheid te verbeteren. Veel van deze doelen zijn onderling verbonden. Sociale rechtvaardigheid kan bijvoorbeeld niet worden gerealiseerd zonder ecologische duurzaamheid (Coote 2014).

\section{Conclusies}

We hoeven niet helemaal opnieuw te beginnen om systeem-gebaseerd veredelen te ontwikkelen. Reeds onder druk van consumentenorganisaties zijn bedrijven gedwongen een maatschappelijk relevant doel ('Purpose') te tonen waarnaar zij streven naast de drie reeds bekende P's van People, Planet, Profit. We hebben laten zien dat de plantenveredelingssector vooruitgang moet en kan boeken door wezenlijk bij te dragen aan Purpose in de zin van de zes eerder genoemde beleidsdoelen.

\section{Gevoel voor urgentie nodig}

Systeem-gebaseerde plantenveredeling, zoals wij het hebben gedefinieerd, vereist een transitie op basis van een goed georkestreerde hervorming van de landbouwproductie en haar instellingen. Deze lezing beoogt niet om een complete routekaart te bieden voor een dergelijke hervorming. Maar zoals ik in mijn beschouwing over de geschiedenis van de biologische zaadteelt en plantenveredeling liet zien, is er behoefte aan een breed gedeeld besef van urgentie om verandering te initiëren. 


\section{Diversiteit nodig}

Om te evolueren naar een systeem-gebaseerde plantenveredeling is een diversiteit aan veredelingsinitiatieven vereist. Initiatieven kunnen beginnen bij diegenen die enthousiaste koplopers willen zijn, voorbeelden in de niche kunnen genereren en ervaring kunnen opdoen hoe obstakels te overwinnen. Er is behoefte aan diversiteit aan agro-ecologische systemen die samen de variatie van functies op meerdere schalen bewerkstelligen die nodig is om echte veerkracht te creëren. Geen enkel op zichzelf staand mechanisme kan het behoud van veerkracht garanderen. Dit geldt zeker voor plantenveredeling. Afhankelijk van de ecologische en culturele context worden verschillende keuzes gemaakt en worden afwegingen anders gemaakt. In de plantenveredeling impliceert het creëren van agrobiodiversiteit tevens een diversiteit aan veredelingsbenaderingen (Louwaars et al. 2011).

Ik hoop dat een systeemgerichte plantenveredelingsoriëntatie, zoals wij hebben gedefinieerd, plantenveredelaars in staat zal stellen niet alleen een inhaalslag te maken, maar ook om leidend te worden in het ecologisch en maatschappelijk veerkrachtiger maken van de landbouw.

\section{Woorden van dank}

In het laatste deel wil ik mijn dank uitspreken aan de vele mensen die mij hebben geïnspireerd en gesteund. In mijn terugblik toonde ik hoe stappen in de ontwikkeling van biologisch zaad en veredelen afhankelijk waren van de juiste kansen en de juiste mensen, op het juiste moment. Ik ben veel mensen dank verschuldigd met wie ik aan dit avontuur heb deelgenomen, die in mij geloofden of met mij geloofden in de mooie uitdaging en mij daarmee de ruimte gaven voor ontwikkeling.

De reis begon met Warmonderhof, waar ik veel inspiratie kreeg van het docententeam in de geest van de jaren ' 70 . In die jaren heb ik veel studenten zien komen en gaan die nu veelal biologisch boer zijn, wat een speciale band geeft als ik bedrijven bezoek.

Ik ben mijn collega's van het Louis Bolk Instituut zeer dankbaar met wie ik altijd in een pioniersgeest heb gewerkt in verschillende teams en in verschillende posities gedurende meer dan 30 jaar.

Ik heb veel geleerd en ben veel verschuldigd, niet alleen aan telers, maar ook aan veel andere partners in de projecten van het Louis Bolk Instituut en 
Wageningen University \& Research, zoals zaadbedrijven, handelsbedrijven en biologische natuurvoedingswinkels. Ik moet de verschillende beleidsmakers van Biologica (nu Bionext) en het Ministerie van eerst LNV, dan EL\&I, vervolgens EZ en nu weer LNV niet vergeten! In mijn reflectie heb ik laten zien hoe belangrijk het was dat instellingen ook meewerkten om nieuwe concepten te kunnen implementeren. Zonder hun inzet zouden we niet zo ver gekomen zijn.

Speciale dank gaat naar die mensen die ik ontmoette in verschillende denktanks, zoals de werkgroep Genenmanipulatie en Oordeelsvorming in de jaren '80 en '9o, en meer recent de leden van de Wetenschappelijke Raad voor Integrale Duurzame Landbouw en Voeding.

Met betrekking tot de Leerstoelgroep Plantenveredeling onder leiding van professor Richard Visser, die mij in deze groep heeft ontvangen, wil ik in het bijzonder professor Evert Jacobsen noemen, die de geestelijke vader van mijn bijzondere stoel was, en mijn mentor door de jaren heen. We hebben elkaar in vele maatschappelijke en wetenschappelijke debatten aan verschillende kanten van de tafel ontmoet en zijn altijd hartelijk en respectvol tegenover elkaar geweest. Ik ben ook de andere collega's van de leerstoelgroep erg dankbaar voor hun openheid en bereidheid om kennis te delen en co-supervisors te zijn van verschillende van mijn promovendi.

En ik ben de sponsors zeer erkentelijk die deze leerstoel door de jaren heen financieel mogelijk hebben gemaakt.

Omdat ik werk altijd met het moederschap combineerde en de afgelopen vijf jaar met wekelijkse oma-dagen, moet ik mijn directe familie en mijn zoons niet vergeten in mijn dankbaarheid. Ze moesten veel verdragen als ik dikwijls fysiek of mentaal te zeer afwezig was - gedreven door mijn passie.

Last but not least, zou ik, te midden van vele dierbare vrienden, speciaal Paul willen noemen die samen met mij dit Wageningse avontuur heeft doorlopen in verschillende rollen, als mijn geliefde partner, echtgenoot, coach en collega. Zonder je niet aflatend luisterend oor, soms strenge begeleiding, gevraagd en ongevraagd advies en mooie redactie van mijn teksten, had ik de opdracht van dit professoraat niet durven aanvaarden. Sommige van mijn promovendi hebben hun waardering uitgesproken voor onze samenwerking door vast te stellen dat ze er twee kregen voor de prijs van één.

Dames en heren, ik kijk met grote tevredenheid en dankbaarheid terug op dit 
werkzame leven waarin ik een bijdrage heb kunnen leveren aan het ontstaan van biologisch zaad en plantenveredeling en hoop nog vele jaren bij te dragen, in een meer vrije rol.

Maar ik zie er ook erg naar uit om meer tijd te hebben voor mijn vier jonge kleinkinderen, door wier ogen ik met grote bewondering het wonder van de bloemen, de bijen en de zaden kan meebeleven.

Ik heb gezegd!

\section{Literatuur}

Arbenz M, Gould D, Stopes C (2016) Organic 3.o - for truly sustainable farming and consumption, IFOAM Organics International, Bonn and SOAAN, Bonn. 28 pp. Te downloaden: https://www.ifoam.bio/sites/default/files/organic3.o_v.2_web_o.pdf

Capra F (1997) The web of life: a new synthesis of mind and matter. Flamingo, London

Coote A (2014) Social justice and environmental sustainability can only be achieved together. Open Democracy UK. https://www.opendemocracy.net/ourkingdom/anna-coote/ social-justice-and-environmental-sustainability-can-only-be-achieved-together

Deru JGC, Schilder H, van der Schoot JR, van Eekeren N (2014) Genetic differences in root mass of Lolium perenne varieties under field conditions. Euphytica 199(1-2):223232.

Dwivedi SL, Lammerts van Bueren ET, Ceccarelli S, Grando S, Upadhyaya HD, Ortiz, $R$ (2017) Diversifying food systems in the pursuit of sustainable food production and healthy diets. Trends in Plant Science 10:842-856

Eosta, Soil \& More, EY, Triodos Bank, Hivos (2017) For food, farming and finance (TCA-FFF). https://www.natureandmore.com/files/documenten/tca-fff-report.pdf

FiBL (2015) Plant breeding techniques - an assessment for organic farming. 2015. FiBL Dossier no 2. FiBL, Frick, Zwitserland. Downloadable: https://shop.fibl.org/ chde/1202-plant-breeding.html 
Kerbiriou PJ, Maliepaard CA, Stomph TJ, Koper M, Froissart D, Roobeek I, Lammerts van Bueren ET, Struik PC (2016) Genetic control of water and nitrate capture and their use efficiency in lettuce (Lactuca sativa L.). Frontiers in Plant Science, section Plant Genetics and Genomics 7, article 343, 14 pp

Khoury CK, Bjorkman AD, Dempewolf H, Ramirez-Villegas J, Guarino L, Jarvis A, Rieseberg LH, Struik PC (2014) Increasing homogeneity in global food supplies and the implications for food security. Proceedings of the National Academy of Sciences USA 111:4001-4006

Kokare A, Legzdina L, Maliepaard C, Niks RE, Lammerts van Bueren ET (2017) Comparison of selection efficiency for spring barley (Hordeum vulgare L.) under organic and conventional farming conditions. Crop Science 57(2):626-636

Lammerts van Bueren ET, Hulscher M, Jongerden J, Ruivenkamp GTP, Haring M, van Mansvelt JD, den Nijs AMP (1999). Sustainable organic plant breeding. Final report: A vision, choices, consequences and steps. Louis Bolk Instituut, Driebergen, the Netherlands

Lammerts van Bueren ET, Struik PC, Jacobsen E (2002) Ecological aspects in organic farming and their consequences for an organic crop ideotype. Netherlands Journal of Agricultural Science 50:1-26

Lammerts van Bueren ET, Struik PC, Tiemens-Hulscher M, Jacobsen E (2003) The concepts of intrinsic value and integrity of plants in organic plant breeding and propagation. Crop Science 43: 1922-1929

Lammerts van Bueren ET, Tiemens-Hulscher M, Struik PC (2008) Cisgenesis does not solve the late blight problem of organic potato production: alternative breeding strategies. Potato Research 51:89-99

Lammerts van Bueren ET, Østergård H, de Vriend H, Backes G (2010) Role of molecular markers and marker assisted selection in breeding for organic and low-input agriculture. Euphytica 175:51-64

Lammerts van Bueren ET, Struik PC (2017) Diverse concepts for breeding for nitrogen use efficiency. A review. Agronomy for Sustainable Development 37(5):50 
Lammerts van Bueren ET, Struik PC, van Eekeren N, Nuijten E (2017) Towards ecological and societal resilience through systems-based plant breeding. A forwardlooking review. (aangeboden aan wetenschappelijk tijdschrift)

Louwaars N, Le Coent P, Osborn T (2011) Seed Systems and Plant Genetic Resources for Food and Agriculture. AO, Rome, Italy. http://www.fao.org/fileadmin/templates/ agphome/documents/PGR/SoW2/tbs_Seed_Systems_081209.pdf

Nuijten E, Janmaat L, Lammerts van Bueren ET (2013) Groene Veredeling: Nieuwe wegen voor veredeling - Sleutelelementen voor samenwerking in de keten. $4 \mathrm{pp}$. Wageningen UR, Wageningen, zie www.groeneveredeling.nl

Nuijten E, de Wit J, Janmaat L, Schmitt A, Tamm L, Lammerts van Bueren ET (2017a). Understanding obstacles and opportunities for successful market introduction of crop varieties with resistance against major diseases. Organic Agriculture (first online). DOI 10.1007/s13165-017-0192-8

Nuijten E, Messmer MM, Lammerts van Bueren ET (2017b) Concepts and strategies of organic plant breeding in light of novel breeding techniques. Sustainability 2017, 9, 18

Osman AM, Bonthuis H, Van den Brink L, Struik PC, Almekinders CJM, Lammerts van Bueren ET (2015) The case of spring wheat Value for Cultivation and Use testing in the Netherlands, Organic Agriculture 5:101-111

Suso MJ, Bebeli PJ, Christmann S, Mateus C, Negri V, Pinheiro de Carvalho MAA, Torricelli R, Veloso MM (2016) Enhancing legume ecosystem services through an understanding of plant-pollinator interplay. Front. Plant Sci. 7:333

Verenigde Naties (2015) Transforming our world: the 2030 Agenda for Sustainable Development. Resolution adopted by the General Assembly on 25 September 2015. United Nations A/RES/70/1. Downloadable: https://sustainabledevelopment.un.org/content/documents/21252030\%20Agenda\%20for\%20Sustainable \%2oDevelopment\%2oweb.pdf 


\section{Sponsoren}

Met dank aan de volgende sponsoren die de buitengewone leerstoel Biologische Plantenveredeling in de verschillende fasen financieel mogelijk hebben gemaakt:

2005 - 2010: Stichting Veenhuizen-Tulp Fonds

2010-2015: Bejo Zaden, Den Hartigh, Eosta, KWS Potato, Meijer Potato, Rijk Zwaan, Stichting Triodos Foundation, Stichting Zaadgoed, Vitalis Biologische Zaden, University Fund Wageningen

2015 - 2017: Bejo Zaden, Den Hartigh, Eosta, KWS Potato, Rijk Zwaan, Stichting Triodos Foundation, Stichting Zaadgoed, Vitalis Biologische Zaden. 



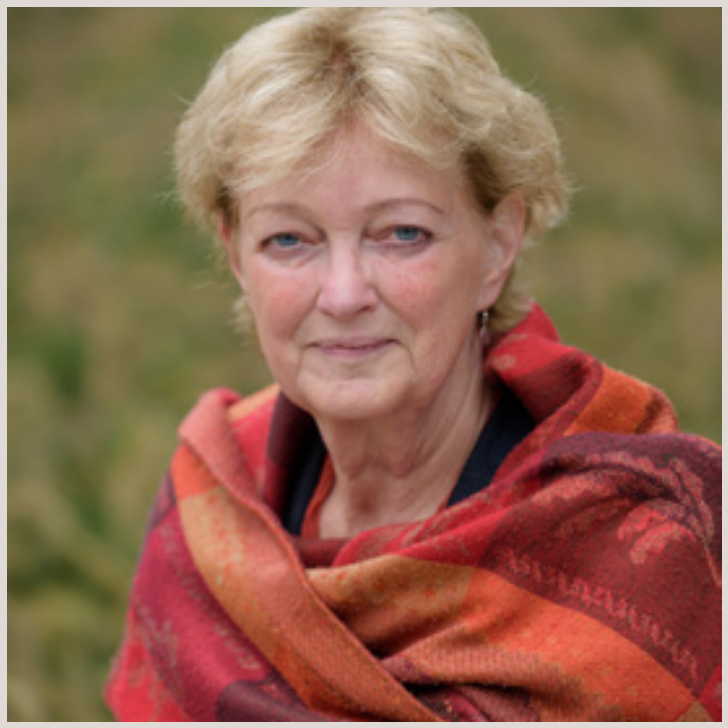

Prof. dr. ir. Edith Lammerts van Bueren

Biologisch veredeling is niet zozeer veredelen voor een andere markt, als wel veredelen voor een ander managementsysteem dat gericht is op het verbeteren van de ecologische veerkracht van de landbouwsystemen terwijl het onafhankelijk is van externe chemische inputs.

Zowel biologische als gangbare veredeling zullen ook andere gebieden van duurzaamheid moeten ontwikkelen die met sociale veerkracht samenhangen en dat vraagt een integrale aanpak.

Ik hoop dat een systeemgerichte plantenveredelingsoriëntatie, zoals hier is gedefinieerd, plantenveredelaars in staat zal stellen leidend te worden in het ecologisch en maatschappelijk veerkrachtiger maken van de landbouw. 